\title{
ANALISIS KASUS MENGENAI PROBLEMATIKA PERSAMAAN LOGO STARBUCKS DENGAN AHLI KOPI LAMPUNG (AKL) TERKAIT SOMASI MEREK DALAM HKI
}

\author{
Oleh \\ Okta Ainita $^{1}$, Angga Alfiyan ${ }^{2}$, Aprinisa $^{3}$ \\ FAKULTAS HUKUM UNIVERSITAS BANDAR LAMPUNG \\ Jalan Zainal Abidin Pagar Alam. No 26, Labuhan Ratu, Bandar Lampung \\ Email: \\ Okta.anita@ubl.ac.id; angga.alfian@ubl.ac.id; aprinisa@ubl.ac.id
}

\begin{abstract}
ABSTRAK
Indonesia sebagai negara kepulauan yang memiliki pengetahuan, tradisi dan budaya dan iklim tropis yang menghasilkan berbagai macam barang/produk yang mempunyai potensi ekonomi yang tinggi sudah seharusnya Indonesia mempunyai suatu konsep perlindungan hukum atas barang/produk yang ada sehingga dengan nilai ekonomi yang ada dapat mewujudkan kesejahteraan bagi rakyatnya. Permasalahan yang terjadi di bidang Kekayaan Intelektual di beberapa Indonesia, sangat menginginkan perlindungan hukum atas Kekayaan Intelektual. Perlindungan dimaksud agar pemilik Kekayaan Intelektual baik perorangan, kelompok atau badan usaha dapat menggunakan haknya atau mengeksplorasi kekayaannya dengan aman yang pada gilirannya dapat menciptakan iklim ekonomi dari hasil yang dikaryakannya dan dapat menciptakan iklim ekonomi juga bagi negara sehingga dapat memberikan manfaat dan kesejahteraan bagi bangsanya karena adanya perlindungan. Memberikan perlindungan Kekayaan Intelektual kepada masyarakat merupakan suatu konsep dari rechtstaat, yang mengutamakan prinsip wetmatigheid. Selain konsep rechtstaat ada juga konsep the rule of law yang memberikan perlindungan bagi HAM melalui pelembagaan peradilan yang bebas dan tidak mengikat, dengan mengutamakan equality before the law. Dan adapun metodelegi dalam pengumpulan data dan metode penelitian dalam penulisan ini yaitu mengunakan metode penelitian yuridis normatif, yaitu penelitian di lakukan terhadap perturan perundang-undangan dan norma-norma positif dalam sistem peraturan perundangundangan yang berkaitan dengan permasalahan penelitian. Dan permasalahan yang akan dibahas pada penelitian ini yaitu bagaimana upaya penyelesaian sengketa logo ahli kopi lampung (AKL) dengan starbucks terkait somasi dalam merek HKI, dan bagaimana keadilan hukum yang diterima oleh ahli kopi lampung dalam penyelesaian sengketa logo ahli kopi lampung (AKL) dengan starbucks terkait somasi dalam merek HKI. Penyelesaian sengketa melalui alternative penyelesaian sengketa yang dilakukan dalam bentuk negosiasi bisa
\end{abstract}


dilakukan untuk menjaga reputasi lembaga dan juga reputasi perusahaan. damai dari kedua belah pihak dalam penyelesaian perselisihan merek. Starbucks mencabut somasi yang diberikan pada pemilik Ahli Kopi Lampung, Karena tidak ditemukannya unsur Persamaan antara kedua logo tersebut.

Kata Kunci : Kekayaan Intelektual, Logo, Persamaan

\section{ABSTRACT}

Indonesia as an archipelago that has knowledge, tradition and culture and a tropical climate that produces a variety of goods / products that have high economic potential should Indonesia have a concept of legal protection of existing goods / products so that the existing economic value can realize prosperity for its people. Problems that occur in the field of Intellectual Property in some Indonesia, really want legal protection for Intellectual Property. Protection is intended so that the owner of Intellectual Property either individuals, groups or business entities can use their rights or explore their wealth safely which in turn can create an economic climate from the results of his work and can create an economic climate for the country so that it can provide benefits and welfare for its people because of protection. Providing intellectual property protection to the community is a concept of rechtstaat, which prioritizes the wetmatigheid principle. In addition to the concept of rechtstaat there is also the concept of the rule of law which provides protection for human rights through the institutionalization of a free and non-binding judiciary, by prioritizing equality before the law. And as for the methodology in data collection and research methods in this writing that is using normative juridical research methods, namely research conducted on the regulation of legislation and positive norms in the legislation system relating to research problems. And the problems that will be discussed in this study are how the efforts to resolve the dispute of the Lampung coffee expert logo (AKL) with Starbucks related subpoena in the IPR brand, and how legal justice received by the Lampung coffee expert in the resolution of the Lampung coffee expert logo dispute (AKL) with Starbucks related to subpoena in the IPR brand. Dispute resolution through alternative dispute resolution conducted in the form of negotiations can be done to maintain the reputation of the institution and also the reputation of the company. peace from both parties in resolving brand disputes. Starbucks revoked the subpoena given to the owner of Lampung Coffee Expert, because no element of Equality was found between the two logos.

Keywords : Intellectual Property, Logo, equation

\section{PENDAhUluan}

Negara Hukum diberbagai negara
memiliki latar belakang sejarah dan
pemikiran yang berbeda. Konsepsi negara
hukum dianggap sebagai terjemahan dari
dua istilah yaitu rechtstaat dan the rule of

law. Kedua konsep ini biasanya berkaitan dengan konsep perlindungan hukum, dimana kedua konsep ini mempunyai latar belakang yang berbeda walaupun pada intinya keduanya menginginkan perlindungan bagi HAM melalui lembaga peradilan yang bebas dan tidak memihak 
sebagaimana telah dituangkan diatas. Istilah rechtstaat banyak dianut di negaranegara Eropa Kontinental yang bertumpu pada sistem civil law yang mengutamakan prinsip wetmatigheid yang kemudian disamakan dengan rechtmatigheid sedangkan the rule of law banyak digunakan oleh negara-negara Anglo Saxon yang bertumpu pada sistem comman law lebih mengutamakan prinsip equality before the law. Walaupun kedua istilah ini berbeda namun keduanya memberikan kedudukan yang sama dihadapan hukum.

Konferensi Bangkok yang dilaksanakan tahun 1965 merumuskan kembali ciri-ciri konsep negara hukum yang dinamis atau negara hukum material sebagai berikut: (Mahmud MD 2015:63)

1. perlindungan konstitusional, artinya selain menjamin hak-hak individu konstitusi harus menentukan pula cara prosedur untuk memperoleh perlindungan atau hak-hak yang dijamin;

2. adanya badan kehakiman yang bebas dan tidak memihak;

3. adanya pemilihan umum yang bebas;

4. adanya kebebasan menyatakan pendapat;

5. adanya kebebasan berorganisasi dan beroposisi
6. adanya pendidikan kewarganegaraan.

Sedangkan negara hukum formal didasarkan pada paham legisme yang berpandangan bahwa hukum itu sama dengan undang-undang sehingga terhadap tindakan melawan hukum berarti perlu adanya usaha menegakkan undang-undang. Dalam konferensi tersebut negara hukum terbagi dalam dua arti yakni dalam arti material dan arti formal. Indonesia merupakan negara yang berdasarkan atas hukum (rechtsstaat) dan tidak berdasarkan atas kekuasaan belaka (machtsstaat). Ini berarti bahwa sejak kemerdekaan bangsa Indonesia berketetapan. Hak merek merupakan hak kekayaan intdustri yang dilindung oleh HKI merek menurut UU No. 15 Tahun 2001 adalah tanda yang berupa gambar, nama kata, huruf, anggka susunan warna dari kombinasi unsur-unsur tersebut yang memiliki daya pembeda dan digunakan dalam kegiatan perdagangan barang atau jasa. pengertian merek pada UndangUndang Baru yaitu UU No 20 Tahun 2016 tentang merek dan indekasi geografis mengalami perubahan dan penjelasan lebih lengkap yaitu tanda yang dapat ditampilkan secara grafis berupa, gambar, logo nama, kata, huruf, anggka, dan susunan, bentu 2 atau 3 
dimensi. Secara formal bangsa Indonesia telah berhasil membangun dan mendirikan sebuah organisasi negara merdeka yang berdasar atas hukum maupun cita-cita/gagasan hukum (rechtsidee) sebagaimana yang terkandung di dalam negara hukum (rechtsstaat) meskipun masih mengandung banyak permasalahan. Permasalahan utama berkaitan dengan perwujudan dan penerapannya dalam sistem hukum nasional Indonesia dewasa ini. Kondisi negara hukum Indonesia yang tercermin dalam sistem hukumnya masih menunjukan keadaan yang sangat memprihatinkan. Akibatnya dunia hukum di Indonesia dewasa ini belum mampu mewujudkan sepenuhnya cita-cita dan harapanharapan sebagaimana amanat UUD 1945. Padahal apabila dikaji lebih dalam UUD 1945 pasal 33 ayat (2) dan pasal 34 sendiri mempertegaskan konsep negara hukum material berintikan pada pembangunan kesejahteraan umum.

Philipus M. Hadjon Mengatakan :

Negara hukum Indonesia menghendaki keserasian hubungan antara pemerintah dan rakyat yang mengedepankan asas kerukunan. Dengan mencerminkan konsepsi negara hukum semua elemenelemen dalam masyarakat dalam melakukan perlindungan hukum dapat diarahkan sesuai dengan asas kerukunan yang didasarkan pada Pancasila dan UUD 1945. (Philipus M. Hadjon 1987:2)

Berdasarkan latar belakang tersebut penulis tertarik untuk membahas mengenai Bagaimana upaya penyelesain Sengketa Logo Ahli Kopi Lampung (AKL) Dengan Starbucks terkait somasi dalam merek HKI? Bagaimana keadilan hukum yang diterima oleh Ahli Kopi Lampung dalam penyelesaian sengketa Logo Ahli Kopi Lampung (AKL) Dengan Starbucks terkait somasi dalam merek HKI? dan didalam penelitian ini peneliti menggunakan metode penelitian yuridis normatif, yaitu penelitian dilakukan terhadap peraturan perundang-undangan dan norma-norma positif dalam sistem perundang-undangan yang berkaitan dengan permasalahan penulisan ini.

\section{PEMBAHASAN}

\section{Upaya Penyelesaian Sengketa Logo ahli Kopi Lampung}

Logo Ahli Kopi Lampung (AKL) yang dipersoalkan Starbucks. Abdillah Muhammad, pemilik merek Ahli Kopi Lampung (AKL) yang digugat Starbucks Corporation menyebutkan tak ada upaya meniru logo Starbucks dalam membuat desain logo AKL. Ia menjelaskan bahwa logo AKL memiliki filosofi dan kekhasan Lampung. Dalam berkas somasi tertanggal 
15 Februari 2018 yang diterima Kontan.co.id, ada dua aspek dari logo AKL yang dinilai Starbucks menyerupai logonya."Merek yang diajukan memiliki persamaan pada pokoknya, dengan merekmerek terkenal Lingkaran Konsentris Starbucks dengan warna hijau yang telah terdaftar milik klien kami. Persamaan tersebut juga terdapat pada penggunaan lukisan mahkota yang sama dengan milik Starbucks yang unik," tulis surat somasi tersebut. Soal logo mahkota yang jadi alasan keberatan Starbucks. Abdillah menjelaskan, hal tersebut merupakan Siger Lampung."Ini adalah simbol dari siger Lampung yang saya buat berjumlah tujuh buah tanduknya pertanda siger berasal dari Lampung Barat. Setiap kabupaten di Lampung memiliki perbedaan jumlah tanduk dalam siger," jelasnya saat dihubungi. Sementara soal warna hijau disebutnya sebagai representasi warna buah kopi saat pertama muncul yang awalnya berbentuk bunga. Somasi Starbucks sendiri dijelaskan Abdillah bermula sejak tahun lalu. Kala itu, ia mengaku mendapat surat dari Ditjen Kekayaan Intelektual Kemkumham tertanggal 12 April 2017 soal keberatan dari Starbucks soal permohonan pendaftaran logo AKL. Sempat mengganti dengan logo itu, namun, kemudian setelah merek saya terdaftar saya kembali menggunakan yang lama," kata Abdillah.
Dalam lampiran surat dari Ditjen KI Kemkumham, Starbucks turut memberikan logo baru bagi AKL.. Dia menjelaskan bahwa pihak Starbucks Corporation tidak meneruskan lagi klaim keberatan logo merek AKL ke Komisi Banding Merek Direktorat Hak Kekayaan Intelektual, Kementerian Hukum dan Hak Asasi Manusia. "Saya mau meluruskan, Starbucks tidak meneruskan, mencabut klaim keberatan dan saya sudah mendapatkan surat terakhir dari Starbucks. Jadi persoalan sudah clear tidak diajukan ke Komisi Banding Merek," kata Abdillah kepada Bisnis. Pengusaha kopi yang berdomisil di Lampung itu menerima surat dari Starbucks Corporation pada 29 Maret 2018. Dalam suratnya, Starbucks menyambut baik bisnis AKL untuk berkontribusi dengan budaya kopi di Indonesia. Dari awal, Abdillah menyakini bahwa logo merek kopinya tidak menjiplak logo Surat Starbucks. Bahkan, pihaknya bersama dengan konsultan telah mendaftarkan mereknya ke Direktorat Merek dan Indikasi Geografis, Kemenkum dan HAM pada 2015."Pada April 2017, saya menerima surat dari Direktorat Merek HKI dan surat Starbucks, mereka keberatan. Padahal, logo saya sudah terdaftar pada 2015 dan pada Desember 2017 lalu keluar sertifikat merek AKL dari Direktorat Merek," kata Abdillah. Dia mengatakan bahwa bisnis kopinya dimulai 
pada 2012 hingga kini. Selain menjual di Lampung, Abdillah juga memasarkan beragam produknya melalui online. Salah satu pelanggannya, jelas dia, bahkan berasal dari luar negeri Australia. Sebelumnya, Starbucks Corporation atau Starbucks Coffee Company menyampaikan surat keberatan atas permohonan pendaftaran merek AKL bernomor agenda D002015027858 di kelas 30, minuman berbahan dasar kopi atas nama Abdillah Muhammad. Dari berkas yang Bisnis kutip, perusahaan yang beralamat di 2401 Utah Avenue South, Seattle, Washington 98134, Amerika Serikat itu memberikan kuasa kepada Evi Triana Wulandari sebagai kuasa hukum untuk menyampaikan keberatan logo merek AKL ke Direktorat Merek dan Indikasi Geografis, tertanggal 12 April 2017. Pihak Starbucks menganggap ada persamaan pokok dengan merek terkenal lingkaran konsentris milik Starbucks dengan warna hijau terdaftar milik AKL mirip dengan logo perusahaan asal Paman Sam tersebut. Persamaan lain, menurut Starbucks, adalah pada barang kedua merek untuk jenis barang yang sama. Jenis barang dari merek yang diajukan berbahan dasar kopi. Namun demikian,

\section{keadilan hukum yang diterima oleh Ahli Kopi Lampung}

Starbucks dalam surat keberatan itu berkeinginan menyelesaikan permasalahan secara damai dan mencabbut Mencabut Somasi Kepaa pengusaha kopi AKL, mengingat kedua belah pihak sangat mendukung perdagangan kopi lokal. Ketika dikonfirmasi, kuasa hukum Starbucks Evi Triana Wulandari hanya mengatakan bahwa pihaknya masih akan berdiskusi terkait dengan somasi merek AKL tersebut.

\section{MEREK}

\section{A. PENGERTIAN UMUM}

Merek merupakan "suatu tanda pembeda" atas barang atau jasa bagi satu perusahaan dengan perusahaan lainnya. Sebagai tanda pembeda maka merek dalam satu klasidikasi barang/jasa tidak boleh memiliki persamaan antara satu dan lainnya baik pada keseluruhan maupun pada pokoknya.

Pengertian persamaan pada keseluruhannya yaitu apabila mempunyai persamaan dalam hal asal, sifat, cara pembuatan dan tujuan pemakaiannya.

Pengertian persamaan pada pokoknya yaitu apabila memiliki persamaan dalam hal asal, sifat, cara pembuatan dan tujuan pemakaiannya. 
Pengertian persamaan pada pokoknya yaitu apabila memiliki persamaan pada persamaan bentuk, persamaan cara penempatan, persamaan bentuk dan cara penempatan, persamaan bunyi ucapan, (yurispudensi MARI).

Merek atas barang lazim disebut sebagai merek dagang adalah merek yang digunakan/ditempelkan pada barang yang diperdagangkan oleh seseorang atau beberapa orang, atau badan hukum.

Merek jasa adalah merek yang digunakan pada jas ayang diperdagangkan oleh seseorang atau beberapa orang, atau badan hukum. Merek sebagai tanda pembeda dapat berupa nama, kata, gambar, hurufhuruf, angka-angka, susunan warna atau kombinasi dari unsurunsur tersebut.

Tanda yang tidak boleh dijadikan merek antara lain :

- Tanda yang tidak memiliki daya pembeda, misalnya hanya sepotong garis, garis yang sangat rumit atau kusut

- Tanda yang bertentangan dengan kesusilaan dan ketertiban umum, misalnya gambar porno atau menyinggung perasaan keagamaan.
- Tanda berupa keterangan barang, misalnya merek kacang untuk produk kacang

- Tanda yang telah menjadi milik umum, misalnya tanda lalulintas, dan Instansi Umum

- Kata-kata umum, misalnya kata rumah, kota dan sebagainya

\section{B. Ruang Lingkup Perlindungan Merek}

1. Definisi merek menurut Undangundang No.14 tahun 1997 pasal 1 butir 1 :

Merek adalah tanda berupa gambar, nama, kata, huruf, angkaangka, susunan atau kombinasi dari unsur-unsur tersebut yang memiliki daya pembeda dan digunakan dalam kegiatan perdagangan dan jasa.

2. Fungsi Merek

Merek dapat berfungsi sebagai :

a. Tanda pengenal untuk membedakan hasil produksi barang atau jasa dari salah satu produksi terhadap produksi lainnya.

b. Sebagai alat promosi

c. Sebagai jaminan atas mutu produk

d. Penunjuk asal barang atau jasa.

3. Perlindungan atas Merek

Sesuai dengan pasal 3 UU No. 14

Tahun 1997, Hak atas Merek adalah

Hak Khusus yang diberikan negara 
kepada "Pemilik Merek Yang Terdaftar" dalam daftar umum Merek untuk jangka waktu tertentu menggunakan sendiri Merek tersebut atau memberi izin kepada seseorang atau beberapa orang secara bersamasama, atau Badan Hukum untuk menggunakannya.

Dari bunyi pasal 3 tersebut ada beberapa hal penting untuk diketahui, yaitu :

- Pemegang/pemilik Hak Merek yaitu : orang (persero), beberapa orang (pemilik bersama), Bdan Hukum yang telah mendapatkan Hak atas Merek yang disebut dengan Merek Terdaftar.

- Perlindungan atas Merej $\mathrm{k}$ Terdaftar yaitu adanya Kepastian Hukum atas Merek Terdaftar baik untuk digunakan, diperpanjang, dialihkan dan dihapuskan. Jangka waktu perlindungan 10 tahun sejak tanggal penerimaan pendaftaran (filing date)

- Sebagai alat bukti bila terjadi sengketa pelanggaran atas Merek Terdaftar.

4. Azas Hukum
Indonesia mengenal atau menganut azas konstitutif yaitu : hak atas Merek diperoleh atas pendaftarannya, artinya pemegang hak Merek adalah seseorang yang mendaftarkan untuk pertama kalinya di kantor Merek.

5. Pelanggaran dan Sanksi

Pelanggaran atas hak-hak Merek sesuai dengan UU No. 14 Tahun 1997 diklasifikasikan sebagai tindak pidana dengan 2 (dua) klasifikasi :
a. Tindak Pidana Kejahatan
b. Tindak Pidana Pelanggaran

Pasal 81:

Pelanggaran atas Hak Merek terdaftar “ yang sama pada keseluruhannya" dipidana penjara paling lama 7 (tujuh) tahun atau denda paling banyak Rp. 100.000.000,- (Seratus Juta Rupiah)

Pasal 82:

Pelanggaran atas Merek Terdaftar "yang sama pada pokoknya" dipidana penjara paling lama 5 (lima) tahun dan atau didenda paling banyak Rp. 50.000.000,- (Lima Puluh Juta Rupiah).

Pasal 84 :

Pelanggaran untuk memperdagangkan barang atau jasa yang bukan mereknya dipidana paling lama 1 (satu) tahun atau dennda paling banyak Rp. 10.000.000,(Sepuluh Juta Rupiah) 
Pelanggaran terhadap pasal 84 dikategrikan sebagai "Tindak Pidana Pelanggaran"

6. Yang berhak mengajukan gugatan atas pelanggaran Hak atas Merek hanya pemegang Hak Merk, yaitu Merek yang telah terdaftar.

7. Bagi Merek tidak terdaftar tidak mendapat perlindungan hukum, artinya tidak berhak mengajukan gugatan atas merek terdaftar maupun atas merek tidak terdaftar lainnya.

\section{a. Pengaturan merek}

Pengaturan merek di Indonesia pertama kali pertama kali diatur melalui Undangundang Nomor 19 tahun 1992 dan telah diubah dengan Undang-undang Nomor 14 tahun 1997 tentabg perubahan atas Undang-undang Nomor 19 tahun 1992 Tentang merek, Setelah ratifikasi anggota WTO Pada tahun 1994 selanjutnya pengaturan merek disesuaikan dengan TRIPs melalui Undang-undang Nomor 15 tahun 2001 Tentang Merek dan terakhir Di ubah Undang-undang Nomor 20 tahun 2016 tentang merek dan indekasi geografis.

\section{b. Tinjauan Umum Kekayaan Intelektual}

Sejarah merekam dari sejak masyarakat kuno hingga saat ini bahwa hak untuk menguasai tanah dan barang oleh seseorang diakui dan dihormati oleh pemerintah untuk melindungi kepentingan dan kekayaan mereka. Seiring dengan perubahan teknologi konsepsi mengenai kekayaan juga mengalami perubahan. Saat ini sistem hukum meletakkan kekayaan kedalam tiga kategori, pertama, sebagian besar masyarakat mengakui hak kepemilikan pribadi dalam kekayaan pribadi, yang dikenal dengan in tangible things; kedua, kekayaan dalam pengertian riil seperti tanah dan bangunan; dan ketiga, kekayaan yang diketahui sebagai kekayaan intelektual. Terkait dengan KI, semua negara mengakui hak kekayaan dalam bentuk produk ide, seperti dalam bentuk hak cipta, paten, merek dan rahasia dagang, tata letak sirkuit terpadu, varietas tanaman. (Carolyn Hotckis 1994:304)

Konsepsi KI didasarkan pada pemikiran karya intelektual yang dihasilkan manusia yang memerlukan pengorbanan tenaga, waktu, dan biaya. Adanya pengorbanan tersebut menjadikan karya yang dihasilkan memiliki nilai ekonomi karena manfaat yang dinikmati. Berdasarkan konsep tersebut maka mendorong kebutuhan adanya penghargaan atas hasil karya berupa perlindungan hukum bagi KI. Secara subtantif, pengertian KI dapat 
didiskripsikan sebagai kekayaan yang timbul atau lahir karena kemampuan intelektual manusia. (Bambang Kesowo 1995: 206).

KI dikatagorikan sebagai hak atas kekayaan yang akhirnya menghasilkan karya-karya intelektual berupa, pengetahuan, seni, sastra, teknologi dll.

\section{c. Arti penting Logo}

Tidak berbeda dengan logo perusahaan yang memiliki arti penting sebagai corporate identity, logo pada instansi pemerintah juga merupakan identitas khusus dari instansi tersebut.Institusi pemerintah sebagai penyelenggara pemerintahanan, memiliki berbagai aktivitas, terutama yang berkaitan dengan regulasi, pelayanan publik, serta penyediaan fasilitas umum. Pemerintah yang berfungsi sebagai pelindung dan pengayom masyarakat serta penyedia pelayanan umum harus memiliki citra institusi yang baik, yakni institusi yang terpercaya, kredibel, dan memiliki reputasi yang baik.

Pembentukan logo juga dapat berperan sebagai salah satu prime mover perubahan budaya kerja dalam sebuah instansi yang akan membantu membentuk persepsi (consumer imagery) terhadap instansi tersebut. Consumer imagery yang terbentuk dari upaya pembentukan citra insitusi pemerintah, merupakan gambaran mental dalam benak masyarakat dan pihak swasta mengenai institusi pemerintah. Persepsi masyarakat dan pihak swasta dalam penyelenggaraan pemerintahan, jika melekat dalam waktu lama, akan membentuk citra pemerintahan dibenak masyarakat dan pihak swasta. Logo instansi pemerintah memiliki nilai simbolik secara individu. Individu mengevaluasinya dengan didasarkan pada konsistensi atau kesesuaian dengan gambaran personalnya terhadap kinerja institusi. (Cahaya Muktar 2003:258)

Peraturan Menteri Pendayagunaan Aparatur Negara (Permen PAN) Nomor 80 Tahun 2012 Tentang Pedoman Tata Naskah Dinas menyatakan bahwa Logo adalah tanda pengenal atau identitas berupa simbol atau huruf yang digunakan dalam tata naskah dinas instansi pemerintah sebagai identitas agar publik lebih mudah mengenalnya. Selanjutnya, Permen PAN Nomor 80 Tahun 2012 juga mengatur bahwa setiap instansi pemerintah harus memiliki dan menggunakan logo. (Permen PAN Nomor 80 Tahun 2012 Tentang Pedoman Tata Naskah Dinas)

\section{d. Kedudukan Logo dalam Hak Kekayaan Intelektual}

Bagi pencipta atau penerima hak untuk mengumumkan atau Dalam lingkup Hak Kekayaan Intelektual, logo termasuk 
memperbanyak ciptaan yang menunjukkan keaslian dalam Dalam Perpres 54 Tahun 2010 mengatur bahwa pelaksanaan dalam kategori hak cipta sehingga memungkinkan untuk lapangan ilmu pengetahuan, seni dan sastra. Sedangkan sayembara dilaksanakan oleh Unit Layanan Pengadaan (ULP)/ mendapatkan perlindungan hukumberdasarkan Undang apabila dielaborasi lebih lanjut, hak eksklusif bagi pencipta/ Pejabat Pengadaan yang berada dalam instansi tersebut. Undang Nomor 19 Tahun 2002. Pasal 12 ayat (1) UU Hak Cipta pemegang hak cipta terdiri atas hak moral (moral right) ULP/Pejabat Pengadaan nantinya yang menetapkan mengatur bahwa salah satu jenis ciptaan yang dilindungi dan hak ekonomi (economic right). Hak ekonomi adalah persyaratan administratif dan teknis bagi penyedia Jasa yang adalah ciptaan dalam bidang seni yang mencakup: seni rupa hak untuk memperoleh keuntungan ekonomi atas hak akan mengikuti Sayembara. Proses pengadaan seluruhnya dalam segala bentuk, seni lukis, gambar, seni ukir, seni pahat, cipta. Sedangkan hak moral (moral right) adalah hak yang merupakan kewenangan dari ULP/Pejabat Pengadaan mulai seni kolase dan seni terapan.Secara lebih rinci, penjelasan Pasal melindungi kepentingan pribadi atau reputasi pencipta. dari Pengumuman Sayembara sampai dengan Pengumuman
12 ayat (1) huruf f menyatakan bahwa yang dimaksud dengan Hak moral melekat pada pribadi pencipta dan tidak dapat Pemenang Sayembara. gambar antara lain meliputi motif, diagram, sketsa, logo, dan dipisahkan dari pencipta karena bersifat pribadi dan kekal. (Pasal 12 Undang Nomor 19 Tahun 2002. Tentang Hak Cipta).

Perlindungan hukum logo yang masuk dalam lingkup hak cipta menganut asas stelsel deklaratif, artinya hak cipta yang akan dilindungi tidak wajib di daftarkan untuk mendapat perlindungan hukum. Timbulnya perlindungan suatu ciptaan dimulai sejak ciptaan itu ada dan bukan karena pendaftaran. Hal ini berarti suatu ciptaan baik yang terdaftar maupun tidak tetap dilindungi. (Dian Pansela Widya $2012: 85)$

\section{e. Administrasi Hak Kekayaan Intelektual}

Secara institusional, pada saat ini telah ada

Direktorat Jendral Hak Kekayaan Intelektual yang tugas dan fungsi utamanya adalah menyelenggarakan administrasi hak cipta paten, merek, desain industri, dan desain tata letak sirkuit terpadu. Direktorat Jenderal Hak Kekayaan Intelektual (semula disebut Direktorat Jenderal Hak Cipta, Paten dan Merek) dibentuk pada thaun 1998. Direktorat Jendral Hak Kekayaan 
Intelektual yang baik sebagaimana yang diharapkan oleh masyarakat, baik yang berasal dari dunia industri dan perdagangan, maupun dari institusi yang bergerak di bidang penelitian dan pengembangan.

Sejauh ini pegawai di lingkungan Direktorat Jenderal Hak Kekayaan Intelektual berjumlah 450 orang. Dibandingkan dengan yang ada di beberapa negara yang telah maju. Direktorat Jendral HaKI merupakan institusi yang relatif masih muda/naru. Oleh sebab itu, dapat dimaklumi seandainya dalam pelaksanaan tugasnya, masih dijumpai berbagai macam kendala. Walaupun demikian, melalui berbagai program pelatihan yang intensif telah ada beberapa staf yang memiliki pengetahuan yang cukup memadai guna mendukung peningkatan sistem hak kekayaan intlektual sebagaimana diharapkan.

Perlu pula kiranya dikemukakan bahwa dalam rangka lebih meningkatkan pelayanan dan kemudahan bagi masyarakat, sejak januari 2000, pengajuan permohonan hak kekayaan intelektual dapat dilakukan di Kantor-kantor Wilayah Departemen Kehakiman dan Hak Asasi Manusia. Selanjutnya, Kantor-kantor Wilayah akan menyampaikan permohonan tersebut kepada Direktorat Jenderal HaKI untuk diproses lebih lanjut. Di samping itu, pada saat ini, dengan bantuan World Bank sedang dilaksanakan penyempurnaan sistem otomasi di Direktorat Jenderal HaKI yang diharapkan dapat lebih menunjang proses administrasi dimaksud. (Farida Yusvita 2015:35)

1. Bagaimana upaya penyelesain Sengketa Logo Ahli Kopi Lampung (AKL) Dengan Starbucks terkait somasi dalam merek HKI ?

Penyelesaian sengketa melalui, alternative penyelesaian sengketa yang dilakukan dalam bentuk negosiasi yang bisa dilakukan untuk menjaga reputasi lembaga dan juga reputasi perusahaan. damai dari kedua belah pihak dalam penyelesaian perselisihan merek.

2. Bagaimana keadilan hukum yang diterima oleh Ahli Kopi Lampung dalam penyelesaian sengketa penyelesain Sengketa Logo Ahli Kopi Lampung (AKL) Dengan Starbucks terkait somasi dalam merek HKI ?

Starbucks mencabut somasi yang diberikan pada pemilik Ahli Kopi Lampung, Karena tidak ditemukannya unsur Persamaan anatar kedua logo tersebut.

\section{PENUTUP}

Dari hasil penelitian dan pembahasan maka dapat ditarik kesimpulan bahwa:

1. Bagaimana upaya penyelesain Sengketa Logo Ahli Kopi Lampung 
(AKL) Dengan Starbucks terkait

somasi dalam merek HKI ?

Penyelesaian sengketa melalui, alternative penyelesaian sengketa yang dilakukan dalam bentuk negosiasi yang bisa dilakukan untuk menjaga reputasi lembaga dan juga reputasi perusahaan. damai dari kedua belah pihak dalam penyelesaian perselisihan merek.

2. Bagaimana keadilan hukum yang diterima oleh Ahli Kopi Lampung dalam penyelesaian sengketa penyelesain Sengketa Logo Ahli Kopi Lampung (AKL) Dengan Starbucks terkait somasi dalam merek HKI ?

Starbucks mencabut somasi yang diberikan pada pemilik Ahli Kopi Lampung, setelah dilakukan penyelidikan oleh ditjen ki bahwasannya tidak ditemukan unsur menyamai atau menyerupai logo merek dari pihak starbucks, Karena tidak ditemukannya unsur Persamaan anatara kedua logo tersebut.

Saran yang dapat penulis rekomendasikan, dalam hal pendaftaran HKI, secara prioritas sehingga tanggal penerimaan dan sertifikat sesuai dengan pendaftaran merek, bagi penggugat yakni starbuck sebaiknya mecari tahu apakah AKL Telah menyamakan logo starbuck yang tidak sesuai prosedur Ditjen HKI. Ditinjau dari Sudut Pandang HKI Indonesia sudah memiliki perangkat Kerja yang cukup dibidang HKI, persamaan merk dan logo sering terjadi terutama dalam kasus HKI, akan tetapi adannya persamaan warna, bentuk, dan keterpaduan unsur-unsur dalam logo tidak semaunya mengandung unsur penjiplakan, adanya arti simbolsimbol yang terkandung dalam logo tersebut yang di padukan oleh pembuat logo tersebut, seperti kasus yang penulis sampaikan dalam penulisan ini. Pembuatan logo harus sesuai dengan prosedur HKI maka jika terjadi sengketa seperti dalam kasus ini. Sudah terjaminnya kepastian hukum. Pendaftaran merek ataupun logo sangatah penting yang berkaitan dengan bertanggungjawab atas hal yang terjadi dalam sengketa tersebut yang sesuai dengan ditjen HKI sebagaimana mestinya.

\section{DAFTAR PUSTAKA}

\section{Buku}

Bambang Kesowo, 1995 Pengantar Umum mengenai KI di Indonesia”, semarang.

Cahaya Muktar, 2003, Kajian Dalam masalah HKI,Yogyakarta, Grafindo.

Carolyn Hotckis, International Law for Bisnis, New York :McGraw-Hill, 1994.

Dian pansela widya, 2012, Perlindungan Hukum, Malang, Kencana Surya Pustaka,

Farida Yusvita, 2015 Hukum Kekayaan Intelektual, Yogyakarta, Indah Abdi Utama. 
Mahmud MD, 2015 Konsepsi dan Implementasi Negara Hukum Kita. Jakarta, Pustaka Kencana.

Philipus M. Hadjon, Perlindungan Hukum bagi Rakyat di Indonesia, Bima Ilmu Surabaya. 1987.

Perlindungan Hukum, Malang, Kencana Surya Pustaka.

\section{Perundang-Undangan}

Undang Nomor 19 Tahun 2002. Tentang Hak Cipta

Undang Nomor 20 Tahun 2016 tentang merek dan indekasi geografis

Permen PAN Nomor 80 Tahun 2012 Tentang Pedoman Tata Naskah Dinas.

\section{Sumber Lain}

https://ekonomi.kompas.com/read/2018/04 /16/132200826/starbucks-cabut-somasi-

ke-pengusaha-kopi-asal-lampung

https://www.lampung.co/lampung/pengusa ha-kopi-lampung-disomasi-starbucks-apapasal/ 